\title{
Nutritional Evaluation of High Protein Genotypes of Pearl Millet (Pennisetum americanum (L.) Leeke)*
}

\author{
Pheru Singh, Umaid Singh, Bjorn O. Eggum, $\dagger$ \\ Kambham A. Kumar and David J. Andrews $\ddagger$ \\ International Crops Research Institute for the Semi-Arid Tropics (ICRISAT), \\ Patancheru PO 502 324, AP, India
}

(Received 5 August 1986; accepted 29 August 1986)

\begin{abstract}
Three high protein (HP) inbred lines (700112, WC-190 and B-816) of pearl millet were studied for their nutritional quality and the results compared with those of normal protein varieties. The protein content of HP lines showed an average increase of $60 \%$ but the starch and soluble sugars together and the fat content decreased by 40 and 20\%, respectively. Total dietary fibre of the HP lines was about 10\% higher. A decrease (about $20 \%$ ) in the albumin fraction was associated with an increase in prolamin in HP lines. The amino acid composition of the HP lines remained normal except for an approximately $16 \%$ decrease in lysine. However, the total amount of lysine in the sample increased by an average of $37 \%$, as a result of a substantial increase in protein content. True protein digestibility was very high for each line but, expectedly, the biological value was markedly lower. The values for utilisable protein were highest for high protein genotypes. Digestible energy was high in all the genotypes, although slightly lower values were obtained for the HP lines; this was attributed to the fibre fractions.
\end{abstract}

Key words: Pearl millet, nutritional quality, high protein genotypes.

\footnotetext{
*Submitted as J.A. No. 617 by the International Crops Research Institute for the Semi-Arid Tropics (ICRISAT).

† Present address: National Institute of Animal Science, Copenhagen, Denmark.

$\ddagger$ Present address: Department of Agronomy. 279, Plant Sciences, University of Nebraska, Lincoln, NE 68583-0910, USA.
} 


\section{INTRODUCTION}

Pearl millet (Pennisetum americanum (L.) Leeke) is one of the most important cereals in the world. This crop is grown on 26 million hectares, primarily in the hot, drought-prone arid and semi-arid regions of Africa and the Indian subcontinent. In India pearl millet is the fourth most important staple food crop after rice, wheat and sorghum, with an annual production of 4 million tonnes. The genetic improvement of the nutritional quality of cereal protein received worldwide attention after the discovery of opaque-2 maize. ${ }^{1}$ Subsequent research resulted in the identification of Hily and Hiproly genes for higher lysine and protein in barley ${ }^{2}$ and of high lysine genes in sorghum lines possessing a higher protein content. ${ }^{3}$

The improvement of the nutritional quality of pearl millet has received relatively little attention. ${ }^{4}$ At the International Crops Research Institute for the Semi-Arid Tropics (ICRISAT) considerable emphasis has been placed on improving the nutritional quality of pearl millet by breeding. Studies on the relationship between nutritional quality characters and grain yield have suggested that in pearl millet it should be possible to select for increased protein content while maintaining the levels of lysine, without detrimental effect on grain yield or grain weight. ${ }^{5}$ In addition, these efforts have resulted in identification of high protein genotypes in pearl millet. ${ }^{6}$ The objective of this study was to evaluate the nutritional quality of high protein genotypes and compare the results with those of normal varieties.

\section{MATERIALS AND METHODS}

The experimental material for the present study consisted of three inbreds, $700112(19.8 \%)$, WC-190 (16.7\%) and B-816 (14.4\%) with high protein content, and two varieties of normal protein content, ICMS-7703 (9.9\%), a synthetic variety, and WC-C75 (11.3\%), a released commercial variety. High protein (HP) lines, 700112, WC-190 and B-816, and low protein WC-C75 were grown during the summer of 1983 at the ICRISAT Center, Patancheru, near Hyderabad; ICMS-7703 was grown during the rainy season of 1983 at the same location. A large number of $\$ 6$ progenies were grown and the seed of the related progenies from respective genotypes was mixed to prepare the bulk seed of 700112, WC-190 and B-816 lines for the study. WC-C75 and ICMS-7703 were grown in isolated seed multiplications plots. All the genotypes were grown in a replicated trial during the 1985 summer season at the ICRISAT Center in order to confirm the protein levels. All analyses for nutritional quality evaluation were carried out in the seed samples of the 1983 season.

Seed samples $(1 \mathrm{~kg})$ were grown in a Udy cyclone mill using a $0.4-\mathrm{mm}$ screen. Nitrogen content was estimated using the Technicon autoanalyser procedure ${ }^{7}$ and nitrogen values were converted into protein by multiplying by a factor of 6.25 . Finely ground samples were defatted in Soxhlet apparatus using $n$-hexane for chemical analyses as reported in Tables 1-3. 


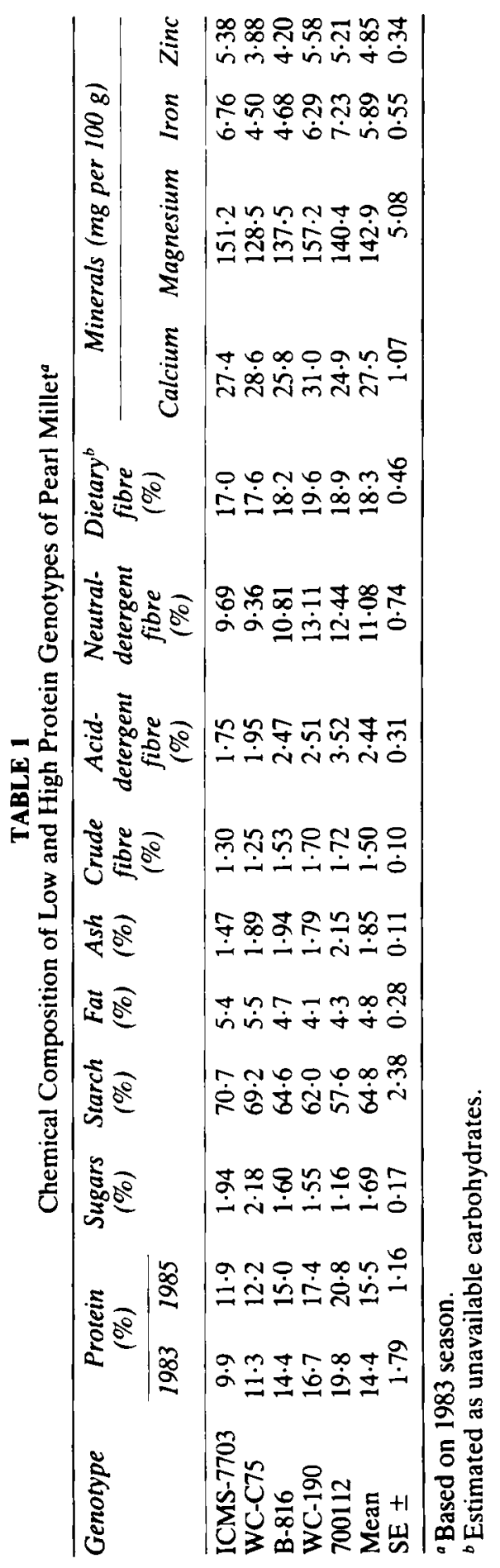


TABLE 2

Seed Protein Fractions of Low and High Protein Genotypes of Pearl Millet

\begin{tabular}{|c|c|c|c|c|c|c|c|}
\hline \multirow[t]{2}{*}{ Genotype } & \multirow{2}{*}{$\begin{array}{c}\text { Protein } \\
(\%)\end{array}$} & \multirow{2}{*}{$\begin{array}{c}N P N^{a} \\
(g \text { per } \\
16 \mathrm{~g} \mathrm{~N})\end{array}$} & \multicolumn{5}{|c|}{ Protein fractions (\%) } \\
\hline & & & Albumin & Globulin & Prolamin & Glutelin & Total \\
\hline ICMS-7703 & 9.9 & 7.0 & $23 \cdot 5$ & 9.4 & 36.9 & $19 \cdot 0$ & $88 \cdot 8$ \\
\hline WC-C75 & $11 \cdot 3$ & $7 \cdot 5$ & $20 \cdot 6$ & $11 \cdot 7$ & $35 \cdot 4$ & $21 \cdot 5$ & $89 \cdot 2$ \\
\hline B-816 & $14 \cdot 4$ & $7 \cdot 9$ & $16 \cdot 5$ & $12 \cdot 0$ & $38 \cdot 7$ & $19 \cdot 6$ & $86 \cdot 8$ \\
\hline WC-190 & $16 \cdot 7$ & $8 \cdot 4$ & $15 \cdot 8$ & $10 \cdot 4$ & $44 \cdot 5$ & $16 \cdot 9$ & 87.7 \\
\hline 700112 & $19 \cdot 8$ & 9.5 & $19 \cdot 5$ & $8 \cdot 6$ & $40 \cdot 3$ & $17 \cdot 7$ & $86 \cdot 1$ \\
\hline Mean & 14.4 & $8 \cdot 1$ & 19.2 & $10 \cdot 4$ & $39 \cdot 2$ & $18 \cdot 9$ & 87.7 \\
\hline $\mathrm{SE} \pm$ & $1 \cdot 79$ & 0.43 & $1 \cdot 40$ & 0.65 & $1 \cdot 57$ & $0 \cdot 80$ & 0.58 \\
\hline
\end{tabular}

a Nonprotein nitrogen.

TABLE 3

Amino Acid Composition (g per $100 \mathrm{~g}$ Protein) of Low and High Protein Genotypes

\begin{tabular}{|c|c|c|c|c|c|c|c|}
\hline Amino acid & $\begin{array}{c}\text { ICMS } \\
7703\end{array}$ & $W C \cdot C 75$ & $B .816$ & $W C-190$ & 700112 & Mean & $S E \pm$ \\
\hline Lysine & $3 \cdot 38$ & $3 \cdot 27$ & $2 \cdot 82$ & $2 \cdot 66$ & $2 \cdot 94$ & 3.01 & $0 \cdot 13$ \\
\hline Histidine & $2 \cdot 29$ & $2 \cdot 48$ & $2 \cdot 27$ & $2 \cdot 34$ & $2 \cdot 21$ & $2 \cdot 32$ & 0.45 \\
\hline Arginine & $5 \cdot 21$ & $5 \cdot 75$ & $4 \cdot 88$ & $5 \cdot 06$ & $4 \cdot 82$ & $5 \cdot 14$ & 0.17 \\
\hline Aspartic acid & 8.92 & 8.89 & 8.78 & 9.02 & 9.02 & 8.93 & 0.04 \\
\hline Threonine & 3.95 & 4.00 & $3 \cdot 85$ & 3.79 & $4 \cdot 01$ & 3.92 & 0.04 \\
\hline Serine & 4.97 & $4 \cdot 85$ & $4 \cdot 64$ & $4 \cdot 77$ & $4 \cdot 87$ & $4 \cdot 82$ & 0.06 \\
\hline Glutamic acid & $20 \cdot 84$ & $20 \cdot 25$ & $20 \cdot 15$ & $21 \cdot 56$ & $20 \cdot 52$ & $20 \cdot 66$ & $0 \cdot 25$ \\
\hline Proline & $6 \cdot 22$ & $6 \cdot 18$ & 6.91 & $6 \cdot 36$ & $6 \cdot 54$ & 6.44 & $0 \cdot 13$ \\
\hline Glycine & $3 \cdot 78$ & $3 \cdot 77$ & 3.49 & $3 \cdot 19$ & $3 \cdot 39$ & 3.52 & $0 \cdot 11$ \\
\hline Alanine & $8 \cdot 26$ & $8 \cdot 04$ & $8 \cdot 48$ & 8.59 & $8 \cdot 37$ & $8 \cdot 35$ & 0.95 \\
\hline Cystine & $0 \cdot 70$ & $1 \cdot 02$ & $1 \cdot 35$ & $1 \cdot 00$ & 1.08 & 1.03 & $0 \cdot 10$ \\
\hline Valine & $5 \cdot 68$ & $5 \cdot 57$ & $5 \cdot 83$ & $5 \cdot 72$ & $5 \cdot 85$ & $5 \cdot 73$ & 0.05 \\
\hline Methionine & 1.66 & $2 \cdot 19$ & $2 \cdot 03$ & 1.41 & $1 \cdot 81$ & $1 \cdot 82$ & $0 \cdot 13$ \\
\hline Isoleucine & $4 \cdot 76$ & $4 \cdot 58$ & $4 \cdot 85$ & $4 \cdot 82$ & $4 \cdot 87$ & $4 \cdot 78$ & 0.52 \\
\hline Leucine & $10 \cdot 50$ & $10 \cdot 44$ & $10 \cdot 72$ & 11.06 & $10 \cdot 81$ & $10 \cdot 71$ & $0 \cdot 11$ \\
\hline Tyrosine & 3.57 & 3.47 & $3 \cdot 41$ & $3 \cdot 32$ & $3 \cdot 32$ & $3 \cdot 41$ & 0.47 \\
\hline Phenylalanine & $5 \cdot 31$ & $5 \cdot 25$ & $5 \cdot 54$ & $5 \cdot 34$ & $5 \cdot 39$ & $5 \cdot 37$ & 0.05 \\
\hline Tryptophan & $1 \cdot 69$ & $1 \cdot 70$ & $1 \cdot 83$ & $1 \cdot 81$ & $1 \cdot 66$ & 1.74 & $0 \cdot 34$ \\
\hline Protein $\%$ & 9.86 & $11 \cdot 25$ & $14 \cdot 35$ & $16 \cdot 70$ & $19 \cdot 89$ & $14 \cdot 41$ & $1 \cdot 81$ \\
\hline
\end{tabular}

Previously described methods were used for determination of ash, fat, crude fibre and acid-detergent fibre, ${ }^{8}$ dietary fibre as unavailable carbohydrates, ${ }^{9}$ neutral-detergent fibre, ${ }^{10}$ soluble sugars and starch, ${ }^{11}$ and minerals. ${ }^{12}$ All these constituents were analysed in duplicate and average values are reported.

Seed proteins were fractionated into albumin, globulin, prolamin and glutelin by successive extractions with distilled water, $0.5 \mathrm{M} \mathrm{NaCl}$ solution, $70 \%$ ethanol and $0.1 \mathrm{~N} \mathrm{NaOH}$, respectively. ${ }^{13}$ A flour to solvent ratio of $1: 20(\mathrm{~g} / \mathrm{v})$ was maintained during extraction. Proteins in the aliquots were estimated as described earlier. For amino acid analysis, defatted samples were hydrolysed in $6 \mathrm{~N} \mathrm{HCl}$ for $24 \mathrm{~h}$ and excess acid was removed using a flash evaporator. Tryptophan was determined after alkali-hydrolysis with $5 \mathrm{~N} \mathrm{NaOH}$. The amino acids were 
analysed in an amino acid analyser (Beckman 119 CL Model). Biological evaluation of the nutritive value of the protein was carried out according to procedures described by Eggum. ${ }^{14}$

\section{RESULTS AND DISCUSSION}

Protein analysis of lines grown during the 1983 summer season, carried out at the ICRISAT Center, India (Table 1) and the National Institute of Animal Science, Copenhagen, Denmark (Table 4), showed small differences which could be due to the different procedures used for analysis. To confirm the values the same genotypes were grown in the 1985 summer season and analysed for protein content (Table 1). Although the values were slightly higher for the 1985 season, the ranking of genotypes did not change. The differences may have been due to seasonal variation. Genotypic differences are quite large, although the possibility of small environmental effects on the protein content of these genotypes could not be ruled out. Large differences in the protein content of these genotypes have been reported with small variation due to the effects of location and season. ${ }^{5.6}$

Differences in the chemical composition of the genotypes of pearl millet are presented in Table 1. Starch, soluble sugar, and fat contents showed significant differences. The protein content of $\mathrm{HP}$ lines was greater by nearly $60 \%$ and starch and soluble sugars together were $40 \%$ lower. The fat content was about $20 \%$ lower and ash values were slightly higher. Calcium, magnesium, iron and zinc contents of the HP lines were similar to normal varieties. Crude fibre (CF), aciddetergent fibre (ADF), neutral-detergent fibre (NDF), and dietary fibre (DF) were slightly higher in HP lines. Total dietary fibre of HP lines, for example, was about $10 \%$ higher than that of normal genotypes. By expressing the differences between these constituents as follows: lignin $=A D F-C F$; hemicellulose $=\mathrm{NDF}-\mathrm{ADF}$; and cellulose $=\mathrm{CF}$, pearl millet contains a considerable about of hemicellulose and this may be disadvantageous from the viewpoint of utilisation of carbohydrates and their calorific value. ${ }^{15}$

The higher protein content of cereals is related to changes in the relative amounts of seed protein fractions. ${ }^{16}$ This was apparent in pearl millet (Table 2).

TABLE 4

Biological Evaluation of Pearl Millet ${ }^{a}$

\begin{tabular}{|c|c|c|c|c|c|c|c|c|c|c|c|}
\hline \multirow[t]{2}{*}{ Genotype } & \multirow{2}{*}{$\begin{array}{l}\text { Protein }^{b} \\
(\%)\end{array}$} & \multicolumn{2}{|c|}{$T D$} & \multicolumn{2}{|c|}{$B V$} & \multicolumn{2}{|c|}{$N P U$} & \multicolumn{2}{|c|}{$U P$} & \multicolumn{2}{|c|}{$D E$} \\
\hline & & $(\%)$ & $(S E)$ & $(\%)$ & $(S E)$ & $(\%)$ & $(S E)$ & $(\%)$ & $(S E)$ & $(\%)$ & $(S E)$ \\
\hline & & 94.4 & & $64 \cdot 6$ & 0.9 & & & & 0.11 & 89.9 & \\
\hline & & & & & 0. & & 0 & & & 0 & \\
\hline & & 94.7 & & & $1 \cdot 2$ & & $1 \cdot 1$ & .41 & 15 & 6.9 & 0.9 \\
\hline & & 9 & 1 . & & $1 \cdot 3$ & & $1 \cdot 1$ & & $0 \cdot 19$ & 6.4 & 0.8 \\
\hline & $21 \cdot 44$ & 94.8 & 1.0 & 57.9 & 1.0 & 54.9 & $1 \cdot 0$ & $11 \cdot 77$ & $0 \cdot 21$ & $82 \cdot 6$ & $1 \cdot 0$ \\
\hline
\end{tabular}

${ }^{a} \mathrm{TD}=$ True protein digestibility; $\mathrm{BV}=$ biological value; $\mathrm{NPU}=$ net protein utilisation $(\mathrm{TD} \times \mathrm{BV} / 100)$; UP=utilisable protein (protein $\times \mathrm{NPU} / 100) ; \mathrm{DE}=$ digestible energy. ${ }^{b}$ Protein $=\mathrm{N} \times 6 \cdot 25$ (dry matter base). 
The albumin fraction of low protein (LP) genotypes was 20.6 and $23.5 \%$, whereas those of HP lines ranged between 15.8 and $19.5 \%$, a $20 \%$ decrease. This decrease was partly compensated for by an increase in the prolamin fraction. Globulin and glutelin fractions were little changed. However, it should be noted that the concentration of albumin fraction was considerably higher in HP lines when results were expressed on a per gram sample basis, due to a $60 \%$ increase in protein content of these genotypes.

Nonprotein nitrogen (NPN) of HP genotypes was higher than that of the LP genotypes, indicating that NPN increased with increasing protein content. A similar positive and significant correlation between NPN and total nitrogen in chickpea has been reported. ${ }^{17}$

Amino acid composition serves as a first approximation of the protein quality of plant proteins. ${ }^{18}$ Lysine and threonine are the most limiting amino acids in cereals. Lysine contents of LP genotypes were 3.27 and $3.38 \mathrm{~g}$ per $100 \mathrm{~g}$ protein, whereas those of HP genotypes ranged between 2.66 and $2.94 \mathrm{~g}$ per $100 \mathrm{~g}$ protein (Table 3 ). This indicated a small decrease (about 15\%) in lysine in HP genotypes compared with an approximately $60 \%$ increase in their protein content, resulting in a $37 \%$ increase in lysine in the sample. No marked difference in tryptophan content of these genotypes was observed. Like other cereals, ${ }^{19}$ pearl millet genotypes containing higher amount of the prolamin fraction had a slightly higher proline content than the LP genotypes but the difference was marginal. No clear-cut differences in the concentration of other essential amino acids between the LP and HP genotypes were evident (Table 3 ).

Rat feeding experiments were conducted to examine the nutritive value of the samples (Tables 4 and 5). True protein digestibility was high and similar for all the genotypes. As expected from the lower lysine values, biological value and net protein utilisation of HP genotypes were lower, but utilisable protein was greater.

TABLE 5

Total Energy and Digestible Energy per Gram Dry Matter of Pearl Millet

\begin{tabular}{lcc}
\hline Genorype & $\begin{array}{c}\text { Total energy } \\
\text { per gram } \\
\text { dry matter } \\
(\text { cal g) }\end{array}$ & $\begin{array}{c}\text { Digestible energy } \\
\text { per gram dry } \\
\text { matter } \\
\text { (cal g) }\end{array}$ \\
\hline ICMS-7703 & 4624 & 4157 \\
WC-C75 & 4647 & 4182 \\
B-816 & 4659 & 4049 \\
WC-190 & 4620 & 3992 \\
700112 & 4703 & 3885 \\
\hline
\end{tabular}

The utilisable protein for HP line 700112 was twice as high as for ICMS-7703 (Table 4). Total energy content per gram dry matter ranged between 4620 and $4703 \mathrm{~g}$ cal (Table 5). Digestible energy per gram dry matter was greater for ICMS$7703(4157 \mathrm{~g} \mathrm{cal})$ than for $700112(3885 \mathrm{~g} \mathrm{cal})$. Such differences in digestible energy have been attributed to differences in carbohydrate fractions. ${ }^{15}$ In the present 
study, all fibre fractions were considerably higher in HP genotypes (Table 1) which might have contributed to the lower values for digestible energy.

\section{CONCLUSIONS}

There were distinct differences in the nutritive value of the genotypes evaluated, in both chemical composition and protein fractionation. Based on the results of these investigations, it is concluded that HP pearl millet varieties are much to be preferred from a nutrition point of view compared with varieties lower in protein content, in spite of the negative relationship between protein concentration and protein quality.

\section{ACKNOWLEDGEMENT}

The authors gratefully acknowledge the technical assistance of P.V. Rao, R. Seetha and C.D. Ramaiah in these studies.

\section{REFERENCES}

1. Mertz, E. T.; Bates, L. S.; Nelson, O. E. Mutant gene that changes protein composition and increases lysine content in maize endosperm. Science 1964, 45, 279-280.

2. Munck, L.; Karlson, K. E.; Hagberg, A.; Eggum, B. O. Gene for improved nutritional value in barley seed protein. Science $1970,168,985-987$.

3. Singh, R.; Axtell, J. D. High lysine mutant gene (hl) that improves protein quality and biological value of grain sorghum. Crop Sci. 1973, 13, 535-539.

4. Hulse, J. H.; Laing, E. M.; Pearson, O. E. Sorghum and the Millets: Their Composition and Nutritive Value. Academic Press, London, 1980, pp. 152-177.

5. Kumar, K. A.; Gupta, S. C.; Andrews, D. J. Relationship between nutritional quality characters and grain yield in pearl millet. Crop Sci. 1983, 23, 232-235.

6. Singh, P.: Singh, U.; Kumar, K. A.; Andrews, D. J. Nutritional quality improvement in pearl millet. Paper presented at the Symposium on Processing of Sorghum and Millets: Criteria for Quality of Grain and Products for Human Food, Vienna, Austria, 4-8 June 1984.

7. Singh, U.; Jambunathan, R. Evaluation of rapid methods for the estimation of protein in chickpea (Cicer arietinum L.). J. Sci. Food Agric. 1980, 31, 247-254.

8. AOAC. Official Methods of Analysis. Association of Official Analytical Chemists, Washington DC, 1975, 12th edn.

9. Southgate, D. A. T.; Geoffrey, J. H.; Englyst, H. The analysis of dietary fiber-the choices for the analyst. J. Sci. Food Agric. 1978, 29, 979-988.

10. Goering, H. K.; Van Soest, P. J. Forage fiber analysis. Agricultural Handbook No 379, ARS, USDA, 1970.

11. Singh, U.; Jambunathan, R.; Narayanan, A. Biochemical changes in developing seeds of pigeonpea (Cajanus cajan). Phytochemistry 1980, 19, 1291-1295.

12. Piper, C. S. (Ed.) In: Soil and Plant Analysis. Hans Publisher, Bombay, India, 1966, pp. 272-275.

13. Singh, U.; Sastry, L. V. S. Studies on the proteins of the mutants of barley grain. 1. Extraction and electrophoretic characterization. Cereal Chem. 1977, 54, 1-12. 
14. Eggum, B. O. A Study of Certain Factors Influencing Protein Utilization in Rats and Pigs, Report 406, National Institute of Animal Science, Copenhagen, Denmark, 1973.

15. Southgate, D. A. T. Fiber and other available carbohydrates and their effects on the energy value of the diet. Proc. Nutr. Soc. 1973, 32, 131-138.

16. Eggum, B. O.; Beames, R. M. The nutritive value of seed proteins. In: Seed Proteins Biochemistry, Genetics and Nutritive Value (Gottschalli, W.; Muller, H. P., Eds). Martinus Nijhoff/Dr. W. Junk Publishers, The Hague, 1983, pp. 499-531.

17. Singh, U.; Jambunathan, R. Relationship between nonprotein nitrogen and total nitrogen in chickpea (Cicer arietinum L.) seed. J. Agric. Food Chem. 1981, 29, 423424.

18. Eggum, B. O. Nutritive value of food crops and factors affecting the utilization of dietary protein and energy. Paper presented at the Second FAO/SIDA Seminar on Field Food Crops in Africa and the Near East, Lahore, Pakistan, 1977.

19. Eggum, B. O. Biological availability of amino acid constituents in grain protein. In: Nuclear Techniques for Seed Protein Improvement, IAEA, Vienna, 1973, pp. 391-408. 